\title{
Regenerative Medicine as an Emergent Cluster in Tampere Region
}

\section{Tuomo Heinonen ${ }^{1}$, Francisco Javier Ortega-Colomer ${ }^{2}$}

\begin{abstract}
Clusters are important for regional economies and emergent clusters are in a key position, as a means of adding more diversification to the current economic activity by involving new technologies and industries. Science-based industries may be the most promising in this regard since they are encouraged to develop and enhance the economic imaginaries of territories under the umbrella of radical innovations or in the name of broadening the current economic model based on mostly traditional industries. Regenerative medicine (RM) could be an example of these so-called emergent clusters. Regenerative medicine is highly dependent on academic research, which means that local territories must fund the research in this field and, hence, they expect some returns as well. As territories do not typically have existing industries specifically in $R M$, these industries must emerge or expand from existing ones. Regenerative medicine involves a wide spectrum of different technologies and industries that are likely to form a cluster and benefit from it if successfully developed. The first aim of this paper is to show how some obstacles eventually impede the proper development of these emergent clusters. The second aim is to shed light on how innovations emerge in the cluster and what are the main implications for the territory. In this study, existing literature is used in order to describe the technology market and commercial aspects of the RM sector. Empirically this study is based on the emergent $R M$ cluster in the region of Tampere in Finland. Analysis of 24 conducted interviews helps to contextualize the emergence of the RM cluster in Tampere, where academia is both the booster and the driver of the emergent RM cluster. Commercialization of research in the RM field is one of the goals at the university, even though there are no commercial outcomes yet available. This study contributes to the understanding of emergent cluster development in science-based industries in their embryonic and early stages. Major challenges are pointed out in an emergent cluster that calls for tailor-made socio-economic policies at the meso-level. Tailored policies matter in science-based clusters, and specific sectors in specific stages of development need specific policies in order to become matured clusters.
\end{abstract}

1 Tuomo Heinonen, M.Sc., Researcher at School of Management, University of Tampere, Kalevantie 4, 33100 Tampere; tuomo.heinonen@uta.fi.

2 Francisco Javier Ortega-Colomer, Ph.D., Universitat Politècnica de València, INGENIO (CSIC-UPV), Camino de Vera s/n, 46022 Valencia, España; fraorco@ingenio.upv.es. 
Keywords: regenerative medicine, emergent cluster, commercialization, innovation, competence bloc, technology market.

\section{INTRODUCTION}

Clusters are important for regional economy as they include different industries working together (Saxenian, 1994). Many traditional clusters e.g. textile, IT, automotive, food, energy, etc., include matured industries (lammarino \& McCann, 2006). As scientific development in universities goes forward, there may be possibilities to create new industries and even new clusters, as many different technologies are often needed in order to fully exploit scientific research (Stoerring, 2007; Stoerring \& Dalum, 2007). In this study, the regenerative medicine (RM) sector is used as an example of a new emergent science-based cluster (Pavitt, 1984). Globally in the RM sector, commercial development is only in its early stage, and innovation is dependent on academia, research centres and hospitals (McMahon \& Thorsteinsdottir, 2013). The future of the RM sector is highly dependent on university-based research, overcoming the financial gap, and the emergence of firms, and in the process of RM sector development, hospitals play a significant role as an endpoint of therapies.

Conceptually this study contributes to the cluster life cycle theory by discussing the commercial engine that enables growth and introducing some empirical evidence from the very early phase of a cluster life cycle. As clusters tend to speed up innovation, firm creation and growth (Baptista \& Swann, 1998), new sectors like RM would presumably benefit clustering. However, due to the small number of commercial entities globally in the RM sector, it is not possible to study matured clusters and their early phases. Instead, an emergent science-based RM cluster in the Tampere region provides an opportunity to scrutinize the very early phases of a potential cluster ex ante. As a result of university-based innovations, it might be possible to see the emergence of new firms and the growth of existing firms who expand their product or service portfolio to the RM sector.

The first aim of this study is to show how some obstacles eventually impede the proper development of these emergent clusters in the RM sector. As the development of commercial RM products costs significantly and takes a long time, firms need to overcome these challenges. The second aim is to shed light on how innovations emerge in the cluster and what are the main implications for the territory. To answer these questions, a case study was conducted in Tampere, Finland. In Tampere, RM-related innovations are developed in academia with great hope for future economic growth, in terms of new firms, expansion of existing firms, and employment. 


\section{Cluster view on RM}

The study of clusters as research objects traces its roots back to the 1990s (Porter, 1990). The main motivation for cluster analysis is to understand how a country/region (or whatever the level is being talked about) gains the competitive advantage of related sectors embedded in a region compared with other global competitors or other lower-scale (local) territories. However, studies on these matters have confirmed the existence of more appropriate conceptual frameworks, mainly from the innovation studies community, where technological change is included as one of the cornerstones to explain the dynamics of the sector. Another dimension included in the innovation systems framework is the multi-level perspective (Geels, 2002), in order to understand the correlation of the forces between actors (distributed agency) at different territorial levels (international, national, regional and local). Among different models proposed by innovation scholars, in this article we used as a theoretical background (Figure 1) the model of innovation system proposed by Arnold and Kuhlmann (2001). These authors propose a model that not only shows but also emphasizes the important aspect of demand affecting both industry and university, and is divided into final demand and intermediate demand. Political sphere influences are also analysed under this framework by including both government and policies that affect brokers between universities and industry, supporting infrastructure, and universities. In summary, three elements are present within this framework: 1) a set of institutions, which promote and enable innovations to occur; 2) the interactions between those above-mentioned players; and 3) the environmental conditions within which the system works. This functional view on innovation systems is treated in the work of Hekkert et al. (2007).

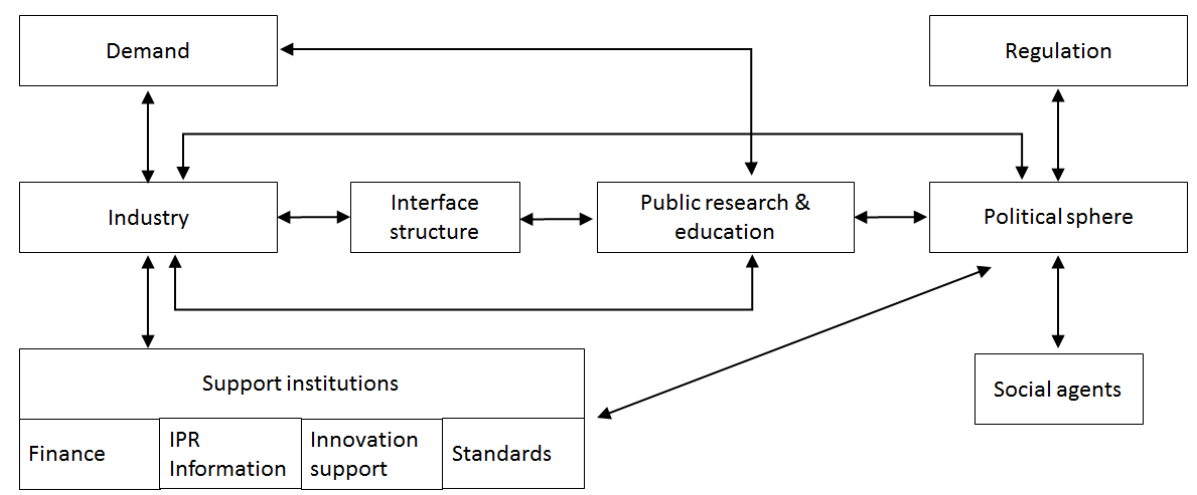

Figure 1. Theoretical framework modified from Kuhlmann and Arnold (2001) Source: Original framework was presented in the order Arnold and Kuhlmann in the publication Kuhlmann and Arnold (2001). 
Demand is an important aspect of the emergent cluster and in the RM sector it is quite complex. Is the customer a patient who gets treatment, the society who benefits from healthier people, or a hospital, which delivers the treatment? As in any sector, depending on the business strategy, firms produce different products at different points of the supply chain - for example, a firm producing compounds as a supplier, a hospital delivering generated bone to the patient, or a firm utilizing stem cells in a gene therapy. The other thing is that innovation requires different competencies in different phases. For this reason, Eliasson and Eliasson (1996) developed the competence bloc theory, which is a good starting point to evaluate the needed competencies for economic growth and successful innovations from both a business and innovation point of view, as the competence bloc is the infrastructure needed to create, select, recognize, diffuse and exploit new business ideas (Table 1). Eliasson and Eliasson (1996) argued that in the emerging biotechnology sector sustainable economic growth would be reached through entrepreneurs funded by venture capitalists, and winners later acquired by established companies acting as industrialists. It thus calls the human competencies that are needed to create new businesses and industrial success (Eliasson \& Eliasson, 1996). This also describes the dynamics in the emergent sciencebased cluster. As universities are innovators, entrepreneurs are needed to carry emerging innovations forward. Competence bloc theory also implies that enough entrepreneurs are located in the territory so that venture capitalists are able to recognize those that are most viable ones. Those firms that are not viable will be terminated fast so that they have an opportunity to select another potential innovation to work on.

Table 1. Actors of competence bloc

\begin{tabular}{|c|c|c|}
\hline Actors & Tasks & $\begin{array}{l}\text { Function in } \\
\text { infrastructure }\end{array}$ \\
\hline Customer & $\begin{array}{l}\text { Active, competent and resourceful. } \\
\text { Products are never better than } \\
\text { customers are capable of demanding. }\end{array}$ & Demand \\
\hline Innovator & Connects technical specializations. & Creation \\
\hline Entrepreneur & $\begin{array}{l}\text { Selects commercially potential } \\
\text { innovations. }\end{array}$ & Selection \\
\hline Venture capitalist & $\begin{array}{l}\text { Recognize and finance commercially } \\
\text { viable opportunities. }\end{array}$ & Recognition \\
\hline $\begin{array}{l}\text { Industrialists, business } \\
\text { leaders and financial } \\
\text { experts }\end{array}$ & $\begin{array}{l}\text { Bring new product to full-scale } \\
\text { production. }\end{array}$ & Exploitation \\
\hline Exit-market & $\begin{array}{l}\text { Expectation for reasonable or better } \\
\text { profit for those who are successful. }\end{array}$ & Incentive \\
\hline
\end{tabular}

Source: Eliasson and Eliasson, (1996). 
The cluster life cycle follows four phases: formation, development, maturity and renewal/decline (Belussi \& Sedita, 2009). First firms are established in the formation phase, followed by a significant growth in the firm population in the development phase. Maturity comes when firm population is stabilized. The competence bloc is especially important in the formation phase of the cluster and its subsequent development phase. In the biotechnology-related industries, start-ups tend to be those that develop innovations and established companies bring those new products to fullscale production. If needed competencies are not available, it is not likely that the development phase of the cluster will continue very far, if it begins at all. As the cluster grows (development phase), local firms are also able to innovate and that way expand their product offerings. At this point, the locus of activity in the emergent cluster shifts from academia to firms, even though academia and hospitals have important roles in creating new knowledge, innovations, being the places for clinical trials, and act as end-users.

\section{DATA AND METHOD}

Empirical insights in this study are based on a single case study conducted in Tampere, Finland. Although it would have been more desirable to include more case studies in the research, the quest for a pluralist approach and a deep perspective allowed us to conduct only a single case study (Yin, 1989). This obviously does not support generalizability, but ensures a richer look at one emergent phenomenon on a global scale (Marshall \& Rossman, 1999). The major share of interviews were conducted at the Institute of Biosciences and Medical Technology (BioMediTech), which is a joint institute of the University of Tampere and Tampere University of Technology. In BioMediTech, the Human Spare Parts research programme was the focus, as it is focusing on RM therapies and technologies. This article emphasizes the emergence of a cluster, which has its roots in the university level. The science-based cluster is in the formation phase, which means that no firms have emerged yet. Thus, inclusion of more firms in the interviews is not plausible and instead interviews focused to the university. Altogether 24 interviews were conducted (Table 2), and in all of the interviews the same semi-structured set of questions was used within the following main themes: research, entrepreneurship, venture finance, legitimization, market formation, hospital environment, and end-value. As a result these interviews gave a coherent view of how different actors at different levels understand the emergent RM cluster in Tampere. Other sources for information were relevant documents, articles and news that were used to describe the history of this emergent RM cluster as well as the industrial sphere. 
Table 2. Conducted interviews, organizations and organization level

\begin{tabular}{lll}
\hline Organization & $\begin{array}{l}\text { Number of } \\
\text { interviews }\end{array}$ & Level \\
\hline BioMediTech (University) & 15 & Local \\
University Hospital of Tampere & 3 & Local \\
Firm & 1 & Local \\
Regional development agencies & 2 & Regional \\
Ministry of Employment and the Economy & 2 & National \\
The Finnish Funding Agency for Technology and Innovation & 1 & National \\
\hline
\end{tabular}

\section{Elements of the emerging RM sector with an impact on industrial development}

In human healthcare, there have traditionally been two main disciplines: medicine and surgery (Polak et al., 2010) and RM could be a third one attempting to revolutionize healthcare. A short, simple definition of RM is provided by Mason and Dunnill (2008a: 4): 'Regenerative medicine replaces or regenerates human cells, tissue or organs, to restore or establish normal function'. Hence, RM uses medicine, surgery, and other disciplines as a multi-disciplinary field (Polak et al., 2010), and even though it is mostly based on cell therapy, i.e. the expected fourth pillar of the healthcare sector alongside pharmaceuticals, biopharmaceuticals and medical devices (Mason \& Manzotti, 2009), it consists of a wide spectrum of different approaches and technologies. The set of potential industries is quite wide and is organised in different levels regarding the supply chain; for example, a firm that decides to concentrate on regenerative compounds is most probably a supplier to a firm concentrating on tissue engineering. Also hospitals are important for progress in RM because they provide the infrastructure for surgery and care of patients, but also ideas regarding current needs where RM therapies might help.

Major expectations for the RM sector are based on the use of stem cells. The biggest hurdle for the use of stem cells derived from human embryos is the ethical and political environment (Harvey, 2010) and in some EU countries it is not possible to have a patent relating to human cells derived from embryos (Mason \& Dunnill, 2008b). In general, there are currently different laws among the nations in the EU and the US regarding the use of embryos (Mason \& Dunnil, 2008b). With induced pluripotent stem cells (iPSC), found in 2006, it might be possible to overcome these hurdles and thus generation of iPSCs might have a major impact on RM (Amabile and Meissner, 2009). However, there are concerns if iPSCs are identical to embryonic stem cells and if not, what is the level of similarity for therapeutic and screening purposes? 
Thus there are some challenges to be met before iPSCs can be used routinely in pharmacological screening and RM (Amabile \& Meissner, 2009).

According to Martin et al. (2006), there were two waves of commercialisation and industry building in the RM sector - the first was between the 1980s and the 1990s, and a second wave from the mid-1990s onwards. In the first wave, the U.S. dominated, but in the second wave, Europe has established a stronger presence. According to Mason (2007), the problem is that funding in the RM sector (somewhere around 2005) has switched from venture capital and pharmaceutical firms to public finance, philanthropists and military products. Venture capitalists are not interested in investing in firms until later phases of the clinical trials (Parson, 2008). However, start-ups need funding for research, development, small-scale manufacturing, and early clinical trials (Mason \& Dunnil, 2008b). Parson (2008) believes that for the majority of firms the future will depend on the possibility of moving forward from start-up-funds to later stage funds to sustain their products through clinical trials. For making this possible, one of the most relevant needs start-up companies in the RM sector is a competent management group (Johnson et al., 2011). However, Parson (2008) points out the limits of a start-up company in the RM sector, where a large amount of cells are needed for treatment in a large patient population and a small startup company may not be large enough to conduct the required trials. Hence, another strategy for an entrepreneurial firm is to be acquired by a bigger company, which is a possibility for a venture capitalist to exit the company if involved, and the established company as an industrialist continues to bring the product to full-scale production.

Metcalfe et al. (2005) made an important point about the sustainability of the new technology and its requirements. According to them, commercial investments are sustainable only if there is a possibility of obtaining a necessary return from the market, and from this point of view, the development of demand and the role of regulation in establishing demand are both important. However, if the market is not fully established, technology development can be supported by non-commercial investment and instead of a technology 'pull', the only option that is left is to try technology 'push' with university based research.

For the companies in the RM sector it is important to have access to cutting edge research (Prescott, 2011). Academia and firms have several innovation co-operation activities, e.g. funding, licensing, consulting and advising between the scientific and technological networks in tissue engineering (Murray, 2002), and scientists with new ideas even have roles in RM firms bringing human and social capital with them (Murray, 2004). However, universities are expected to nurture innovation further in clinical 
trials before establishing start-ups and obtaining venture capital for it; some countries are actually filling this gap by establishing government centres for funding cell therapy clinical trials (Mason et al., 2011). In Finland this is not the reality yet.

Hellman et al. (2011) argued about the need for collaborative interactions between scientists, physicians, investors, attorneys, regulators, political entities and patients in building a biomedical industry. The RM sector will need highly specialized hospitals and day-care centres where cells are implanted and therapies conducted, and thus, training for the clinical community must be conducted in order to be able to use products (Mason \& Dunnil, 2008b). Regulatory bodies, though, are not always up to date about biomedical scientific understanding and possibilities of technology, and thus there are examples of evolutionary trajectories where regulation has co-evolved with innovation sequence and the market (Metcalfe et al., 2005).

Salter et al. (2014) make a distinction between different models in stem cell therapies (Table 3 ). Model I is the only solid scientific innovation model while the rest are so called medical innovation models. Medical innovation in cell therapy is defined the followed way: 'Medical innovation in cellular therapy may be viewed as ethical and legitimate use of non-approved cell therapy by qualified healthcare professionals in their practice of medicine' (Gunter et al., 2010, p. 966). The goal of medical innovation in cell therapy is always to be beneficial for the individual patient while the goal of scientific innovation is to obtain generalizable results (Lindvall \& Hyun, 2009).

Table 3. Differences between stem cell innovation models

\begin{tabular}{|c|c|c|c|c|}
\hline & Model I & Model II & Model III & Model IV \\
\hline $\begin{array}{l}\text { Scientific } \\
\text { / medical } \\
\text { innovation }\end{array}$ & $\begin{array}{l}\text { Scientific } \\
\text { innovation }\end{array}$ & $\begin{array}{l}\text { Medical } \\
\text { innovation } \\
\text { (Western) }\end{array}$ & $\begin{array}{l}\text { Medical } \\
\text { innovation (non- } \\
\text { Western) }\end{array}$ & $\begin{array}{l}\text { Medical and } \\
\text { scientific } \\
\text { innovation }\end{array}$ \\
\hline Regulation & $\begin{array}{l}\text { Traditional with } \\
\text { clinical trial, } \\
\text { advanced therapy } \\
\text { medicinal product } \\
\text { (ATMP) in EU }\end{array}$ & $\begin{array}{l}\text { ATMP Hospital } \\
\text { exemption }\end{array}$ & Not regulated & $\begin{array}{l}\text { Not regulated / } \\
\text { traditional with } \\
\text { clinical trial }\end{array}$ \\
\hline Patient \# & Unlimited & $\begin{array}{l}\text { Single / small } \\
\text { group }\end{array}$ & Large population & Large population \\
\hline Product & Clinical application & $\begin{array}{l}\text { Non-routine } \\
\text { exercise }\end{array}$ & Clinical application & Clinical application \\
\hline Ethics & $\begin{array}{l}\text { Knowledge } \\
\text { generation }\end{array}$ & Patient benefit & Patient benefit & Patient benefit \\
\hline $\begin{array}{l}\text { Acting } \\
\text { professional }\end{array}$ & Scientist & Clinician & Clinician & Scientist / clinician \\
\hline
\end{tabular}

Source: Salter et al. (2014). 
Gunter et al. (2010) claimed that those patients not eligible for controlled clinical trials should be able to choose unproven but scientifically validated cell therapy options. In addition, it is said that it is not optimal to develop stem cell therapies only via the medical innovation pathway alone (Lindvall \& Hyun, 2009). Thus, there might be a place for scientific and medical innovation paradigms in the cell therapy sector, if researchers are competent and patients are truthfully and ethically informed (Gunter et al., 2010).

Currently in developed countries, it is almost impossible to bring new therapies to clinical use without any regulatory approval, as long as there is medical technology innovation involved. There are some exceptions, e.g. advanced therapy medicinal product (ATMP) Hospital Exemption in EU, which allows hospitals to do some clinical treatment without any clinical trials, but in these cases, treatment has to be non-routine treatment and regulatory authority has to approve it. Another problem is that there is no scientifically proven evidence that a product is efficient and safe. The other questions are whether these non-routine treatments can be understood as a new medical practice and what their role is in the development of the RM sector. With accumulated expertise, it is possible to serve patients, but it means that because of the ATMP Hospital Exemption regulation, treatments have to be conducted in the granted country and due to non-routine treatment not all who want to get it are eligible. Thus, regulation restricts medical innovation in very fundamental way, but also makes it safer.

\section{EMERGENT RM CLUSTER IN TAMPERE}

\section{History}

Biomaterial research has a long history in Tampere. Already in the 1980s there was advanced research in biomaterials, and researchers were able to develop a bio-absorbable screw to repair bone fractures (Sotarauta \& Mustikkamäki, 2015). Two decades later researchers in Tampere were able to grow real bone tissue from patients' own stem cells. This progress and development did not happen in a vacuum, but included several organizations and programmes. One of the steps forward with regard to the RM sector in the Tampere region was the establishment of BioneXt Tampere (2003-2010). This organization was established in order to support tissue engineering, biomaterials, bio-ICT and immunology fields in acquiring needed expertise and investments.

Several organizations in Tampere established Regea in 2005 as a research institute with a focus not only on basic research but especially on clinical applications. One of the successes at that time was that the city of Tampere endowed a professorship for stem cell research to Regea. According to 
interviewee: "the vision was from the beginning that this research generates commercial outputs". Indeed, only two years after the establishment of Regea they were able to conduct an operation with a real patient, in which a part of the patient's missing jawbone was reconstructed with stem cells taken from the patient's own fatty tissue. Over the ensuing years, this therapy has been used successfully in over 25 patients in cooperation with Finnish university hospitals, and lately in Tampere. Before the establishment of Regea, a good manufacturing practices (GMP) level laboratory in the University of Tampere was crucial in the development of the clinical tissue engineering application.

Some other initiatives also built a basis for the formation phase of the RM cluster in Tampere. The Biosensing Competence Centre (2007-2010) focused on regional strengths of tissue engineering and clinical diagnostics, and the national programme HealthBIO (2007-2013) focused and contributed to the biotechnology field in Tampere. HealthBIO was a biotechnology cluster focused on utilizing high competence in business and on developing supporting structures. In 2011, the University of Tampere and Tampere University of Technology established BioMediTech as a successor to Regea. BioMediTech continued the prospective stem cell research and the Finnish Funding Agency for Technology and Innovation (TEKES) granted BioMediTech the research programme, Human Spare Parts, which is still going on. Through this research programme, RM research in Tampere has continued to advance. As all initiatives have aimed to strengthen the biotechnology cluster in Finland and in Tampere, RM applications in particular were seen as a strength in which other competencies could be utilized.

\section{Industrial sphere}

The emergent RM cluster in Tampere includes many potential application areas in stem cell therapies, diagnostics and supporting technologies. Even though the financial need might be too high for stem cell therapies in relation to readily available funding resources, there are still possibilities for other supporting technologies and diagnostics, for example. In the Tampere region, only a few firms purely focus on stem cell-related services or products and the RMfocused industrial sphere is in a very embryonic formation phase. In life science fields, such as devices, ICT, biomaterials, pharma, and services, there are firms focusing on biomaterials and cell-related technologies, and, traditionally, health and biotechnology industries have been successful in Tampere. There have been few initial public offerings from Tampere in the biotechnology sector. One was in 1997 to the New York stock exchange and the other was in 2004 to the London stock exchange, even though experience from these did not really stimulate the growth of the local ecosystem on a large scale. 
Regarding cluster development in the RM sector, there have been only a few small firms in Tampere dealing with stem cells. However, the Tampere region still has some potential firms in the biotechnology industry that could acquire potential RM-related applications and innovations from BioMediTech in later phases of cluster development. In this sphere, there have been over 10 spin-offs from the research groups in Tampere. The good thing for the local industrial sphere is that BioMediTech actively seeks opportunities to commercialize their research, and for this purpose they have established several internal projects. However, currently there are no active connections between small local firms and BioMediTech in order to exploit the potential applications BioMediTech has developed. Instead, BioMediTech seeks partners from established bigger companies abroad.

Therapy development is expensive in the RM sector and both BioMediTech and their stakeholders have acknowledged this. Around 2008, there was a plan to establish the Hospital of Advanced Therapies (HAT) to provide those therapies that Regea (predecessor of BioMediTech) was developing at that time, but eventually the implementation of HAT was suspended. BioMediTech has continued to deliver bone growth therapies through the hospital, though, and the university has planned to start a preclinical study to prepare official clinical trials in collaboration with other organizations. This therapy has in many ways been instrumental in this formation phase of the emergent RM cluster in Tampere, as it has shown the benefits that RM therapies can provide to patients, and has given proof to and hope for actors that there are possibilities in this sphere. It is very important for the potential development phase of this cluster that this therapy, as well as other potential therapies, will be transferred at some point to companies that have a link to the Tampere region. As suggested in the competence bloc theory, an entrepreneurial firm is most likely to carry potential innovation at the beginning and then later an established firm is likely to acquire it. Hence, it is important that BioMediTech also actively seeks connections to established companies and in that way make the Tampere region known to the potential industrialists. However, at the same time there is a need for local start-ups that can acquire innovations from BioMediTech, but also strengthen the competence bloc in the Tampere region in order to shape the way for the development phase of the cluster.

The Finnish market for all potential products is small, locally, and firms must look towards international markets to find customers. As one of the interviewees in the university said: "Whatever products we start to produce here, the market is global". Thus, international conferences are important for practitioners, being places where it is possible to see in what direction the field is heading. It also means that patenting must be done wisely and rationally with regard to potential markets. This brings challenges for 
BioMediTech (and all the universities) as they have to make choices as to what to patent and where. There is also a tension between scientific publications and patenting, which in some cases forces universities to patent too early so that researchers are able to publish their work. Potential market for products is the key thing for firms, and especially in the cases where university research is transferred to start-ups or existing firms. It is important for the emergent RM cluster in Tampere that potential firms are going to stay in the region and establish a manufacturing function. The development of a cluster might be the reason why firms choose to stay in Finland, even though the cost of manufacturing might be relatively high. It is important for local firms that they have the possibility to scale-up their production. However, currently the local competence bloc lacks industrialists but also related services like companies that can help to scale up the cell production. It is important for the process from the formation phase to the development phase of a cluster, such as the current science-based emergent RM cluster, that the emergence of local businesses and supporting services happens simultaneously. Locally there is also a need for a stronger interface structure between industry and academia in the RM fields.

\section{Demand}

Multi-level demand has been the most important aspect in this formation phase of the emergent RM cluster in Tampere. One of the other most important aspects is that real patients have been treated with bone growth therapy. This therapy is for patients' benefit, and in the end it is patients who create a demand for new RM therapies in general. In health care, however, hospitals and clinicians are the main actors who make decisions about the use of new therapies in patient care. Hence, clinicians contribute to this demand as well. This has also been the case in Tampere, as the clinical need has been the driving force for RM therapies and research and hospitals have been very active in creating the demand for this experimental therapy, which has not undergone any official clinical trials yet. As the development of RM therapies needs specialized tools, it also creates a demand. Solutions in the market are not always sufficient, and, hence, stem cell biology groups within academia have created a demand for better tools. As BioMediTech is a joint institute of two universities and there are research groups with technical disciplines in the Human Spare Parts programme, technology groups have been able to provide solutions to this internal demand from stem cell groups. In most industries, firms are the manufacturers of products and services. Here this is not yet the case. Instead, the universities and hospitals have been the main actors in the development of the new therapy and providing it to patients. In 
order to proceed to the development phase of the RM cluster, the industrial sphere must take the lead.

The situation is currently positive in terms of new potential commercial offerings either for start-ups or established companies. Innovations created in BioMediTech (both tools and therapies) cannot be commercialized and brought to full-scale production without firms, and as scientific development advances, it will create more demand for different tools. Similarly, development of therapies requires full-scale production solutions. Hence, it seems that there are possibilities for the transition from the formation phase to the development phase of the cluster. However, for the future, an important question is whether the demand will grow big enough to attract investors and firms as well. Customers are in a key position in this as they create such a demand. Now academia is a customer for itself, but in the future, other customers will also be needed in order to develop the competence bloc.

\section{Education and research}

As in any university, education and research are two pillars in BioMediTech. There is also a third strong pillar, which is innovation promotion. Innovation is the key factor for possibilities for future economic activity in the RM sector in Tampere. As not all graduates are able to continue their studies as PhD students, the need for jobs is high and the supply of competent employees is secured. Regarding research, in recent years, one of the biggest research programmes in Tampere has been the Human Spare Parts research programme. In this programme, Tampere University of Technology and the University of Tampere combined their expertise in supporting technologies and stem cell biology. Together four groups from the field of technology and four groups from the field of stem cells joined the programme, in which the focus was on the advancement of health care with new therapies and solutions. In general, research groups in BioMediTech have a high rate of international collaboration.

The combination of stem cell research and technology expertise is important in advancing the RM sector. Because of this, it is possible to develop highly specialized solutions for stem cell research that are otherwise very difficult to find in the technology market. As these solutions have emerged from the research of BioMediTech, there are also other potential users for them, which creates opportunities for firms to grow and expand their product portfolio. The advantage is that researchers have already tested these new technological tools in practical work situations. These technologies are highly necessary in stem cell research and in subsequent applications. Hence, these form an important industry in the RM cluster, where other research groups in the RM sector are also potential customers internationally. 
Hospitals are important in the RM sector, and research groups work in close collaboration with clinicians and hospitals, because this is the most efficient way to direct the research along the right path. The combination of university and hospital is also essential in order to provide bone growth therapy for patients. Currently, with regard to the utilized bone growth therapy, bone products are made in the university's clean room. From there the products are transferred to the hospital where hospital staff conduct clinical operations for patients. Without this close connection, it would be very difficult to see whether potential treatment really works. It is also beneficial for firms, as hospitals are experienced in working with stem cellbased products, which makes it easier for firms to approach them.

The interface structure between industry and academia is a part of the operations in BioMediTech as they approach industry directly. An important aspect in the emergence of the RM cluster in Tampere is the development of a proof of concepts (PoC) from the research of BioMediTech. With the PoC approach, BioMediTech is able to reduce the risk of failure in the technology transfer phase (Heinonen, 2015). According to an interviewee: "it is wise to stay in the university and conduct research, and progress until there is a clinical proof of concept". The development of PoCs is an efficient tool by which it is possible to combine technology and experience in the same package and transfer it to a firm. As the university is conducting the initial market studies and developing working prototypes, it is easier for firms to continue the development and be more prepared to exploit innovations commercially as well.

\section{Legal and political sphere}

BioMediTech and other organizations as well as firms, are part of the Finnish innovation system. This system consists of several organizations that are interlinked with each other. According to Kotiranta et al. (2009), even though there are several public organizations embedded in the national innovation system, only a few of them are relevant to the firms. Among those relevant organizations, the Technical Research Center of Finland (VTT) is relevant for large companies, and for all companies, universities and the Finnish Funding Agency for Technology and Innovation (TEKES) are relevant, according to the survey made by The Research Institute of the Finnish Economy (Kotiranta et al., 2009). Initiatives in Tampere are in line with the overall Finnish national innovation policy, which is rather technology-driven (Kotiranta et al., 2009). At ministry level, initiatives and actions are dependent on the political system, which also has implications at a governmental organization level. Hence, elections could radically change the chosen path. However, in Tampere the 
exception was, as discussed in section 5.3 about demand, that clinical need triggered the scientific advances and the development of needed solutions. From the outset, regional actors have understood that to be in the front line, scientific and development efforts need to be focused, and one of the results of this was the establishment of BioMediTech and the Human Spare Parts research programme. Regional initiatives have had a strong influence and significance, and in a sense, the development of potential innovations was a bottom-up process that was first supported by regional development agencies and later by national-level innovation agencies.

In general, new therapies in the RM sector need to fulfil the regulatory requirements, including clinical trials, which has direct implications for both emerging firms and existing firms hoping to develop in the field of RM therapies. In the EU, it is possible to deliver RM therapies under a special ATMP hospital exemption, in which there is no need for clinical trials. National authorities are able to decide how many treatments it is possible to deliver with hospital exemption, and in Finland there is no strict limit in place. The ATMP hospital exemption is beneficial for the emergence of the RM sector in the EU, but for firms it is contradictory, as it makes it possible for governments to provide RM therapies with no clinical trials, and at the same time firms need to fulfil strict regulative requirements in order to exploit these commercially. In Tampere, ATMP hospital exemption is the way to provide treatments with bone growth innovation in RM. With regard to this therapy, there are plans to conduct official clinical trials in order to commercialize it. As regulatory approval is essential for new therapies, BioMediTech has a close connection with regulators in order to find a way to fulfil all requirements correctly. Even more, as one interviewee in BioMediTech said: "regulation has actually provided help to us". Without regulation there would be always a little uncertainty how things should be done, and clear and efficient regulation might be a facilitator of medical innovation (Messenger \& Tomlins, 2011). As the RM sector includes different technologies, not all of them are regulated as highly as stem cell therapies. Products that are solely for research purposes are not regulated at all. This enables technology transfer from BioMediTech to firms to take place more easily and faster.

Apart from developed technologies, use of the technologies also has consequences and challenges that are worth mentioning. For instance, it was essential for the first operations with regard to bone growth therapy, that the board of directors in the local hospital agreed and gave permission to conduct experimental treatment for patients (Mesimäki et al., 2009). However, the GMP level laboratory is crucial in the cases where cells for human treatment are prepared and, luckily, the GMP level laboratory and clean rooms were already in existence at the time of the first patients being 
treated. In Finland, in those cases where clinicians did everything carefully, individual clinicians are not alone responsible if something goes wrong. This is an advantage for experimental therapies, as clinicians have more courage to perform operations. There are neither problems with public opinion nor high debate regarding their ethicality, which is very favorable for the use of stem cells in therapies.

\section{Funding}

Public funding is a key factor in the development of the RM sector in general, and specifically in the formation phase of the local cluster. In addition to the normal funding universities seek and receive for research, Regea and BioMediTech have received much public funding from TEKES, the Academy of Finland, the Council of Tampere Region, and the City of Tampere in order to develop the RM sphere in Tampere. For example, the Council of Tampere Region has provided funding for research facilities that have affected positively the progress in RM research. In 2011, BioMediTech received 10 million euros in funding from TEKES for the Human Spare Parts research programme for the years 2011-2014, which boosted the formation phase of the RM cluster in Tampere region significantly. Lately, TEKES granted another 4.5 million euros for the years 2015-2016. This basic funding for the Human Spare Parts research programme has made it possible to focus on long-term goals and strengthen collaborative structures between research groups.

The advantageous aspect for BioMediTech has been that TEKES funds PoC projects in order to facilitate technology transfer from university to industry. This allows BioMediTech to focus research commercialization on distinct projects that do not affect research projects too much. However, due to stable funding, it is possible in some cases to revert the PoC back to the research programme in order to develop it further. For future products that are based on university research, PoC development is essential. It is important to assess the market potential of these potential products, in order to transfer successfully innovation to industry. As PoC development is important, TEKES provides a financial instrument with which to achieve it. However, as stem cell products require long clinical trials, the financial aid that TEKES provides is not perfectly suitable, as TEKES requires faster outcomes, which are possible in the case of technological solutions. Even though RM cell therapy products are not suitable for PoC funding from TEKES, they are willing to support commercialization efforts in other ways. For example, with regard to bone growth therapy, there are plans to conduct studies toward clinical trials in collaboration with external partners and TEKES is willing to help financially in this process. However, for the development of RM therapies, it is particularly 
important to have an endowment from which early clinical trials are funded in academia, as firms are unlikely to receive venture capital funding for early clinical trials, which are needed for a product to be approved. As one interviewee mentioned: "you can't establish a firm in too early stage. It is really expensive to operate a firm in this field, and it is the reason why venture capital is needed at some point". However, to conduct clinical trials in the university requires a lot of expertise and resources. Even though it is possible to develop products for scientific use at a much faster pace, for the future of the RM sector globally and related clusters, RM therapies are crucial.

\section{CONCLUSIONS AND IMPLICATIONS}

Prerequisite for the emergence of an RM cluster in Tampere is that academia is able to generate enough new knowledge and innovations for firms to use. A growing number of firms are able to exploit university-based innovations, which could lead to the emergence and growth of local firms. The RM sector requires multiple technology disciplines, which means that there might be several opportunities for firms to diversify. This eventually should lead the emergent cluster to a growth path due to the emergence of new firms and the growth (diversification) of existing firms, which subsequently leads to a situation where existing firms need new suppliers and service providers. The competence bloc in this process describes well how new firms emerge in the region and what it required. In the formation phase it seems to be especially important to get bigger companies involved as well, as those can act as industrialists for new companies later. The availability of industrialists is beneficial for both entrepreneurs and venture capitalists.

The main implications for policymakers concern requirements that are evidently important for the emergence of a science-based cluster and its further development from the formation phase to development phase. First, public funding is extremely important, as in the beginning there is no company structure investing in the future. A local cluster needs regionally specified funding schemes in order to conduct research in academia, but also to develop research-based innovations that can be transferred to companies. There should be appropriate funding to conduct early clinical trials in the universities as well, but it is also important to support the collaboration with industry from the very early phases of innovation. Second, collaboration among local agents (both public and private) is necessary in order to exploit fully the capacity in the region by, for instance, avoiding duplicity of efforts from related firms in undertaking a research/innovation project. International collaborations are also highly important in allowing learning, applying funding, and providing a wider demand, to mention just some examples. 
Third, a growing number of firms is especially important for the local cluster. The science-based sector analysed here does not completely fit within the so-called linear model of innovation. On the contrary, it requires a complex interaction and prototyping between relevant actors. Therefore, the growth of firms might be supported by encouraging a practice-oriented environment and hence the use of emerging innovations would be more plausible.

In this study, some major challenges are pointed out regarding an emergent cluster, which call for tailor-made socio-economic policies at the meso-level. Science-based clusters obviously need tailored policies, as sectors are different, but related. Specific policies are also needed in different stages of the cluster life cycle, especially for an emergent cluster to proceed from the formation to the development phase and finally to become a matured cluster. With regard to the emergent RM cluster in Tampere, the development process is long and it might take still years to actually proceed from the formation phase to the development phase.

\section{References}

Amabile, G., \& Meissner, A. (2009). Induced pluripotent stem cells: current progress and potential for regenerative medicine. Trends in Molecular Medicine, 15(2), 59-68.

Babtista, R. \& Swann, P. (1998). Do firms in cluster innovate more? Research Policy, 27, 525-540.

Belussi, F. \& Sedita, S. (2009). Life cycle vs. multiple path dependency in industrial districts. European Planning Studies, 17(4), 505-528.

Eliasson, G. \& Eliasson, $\AA$ (1996). The biotechnological competence bloc. Revue d'Economie Industrielle, 78, 7-26.

Geels, F.W. (2002). Technological transitions as evolutionary reconfiguration processes: a multi-level perspective and a case-study. Research Policy, $31,1257-1274$.

Gunter, K., Caplan, A., Mason, C., Salzman, R., Janssen, W., Nichols, K., Bouzas, L., Lanza, F., Levine, B., Rasko, J., Shimosaka, A. \& Horwitz, E. (2010). Cell therapy medical tourism: time for action. Cytotherapy, 12, 965-968.

Harvey, O. (2010). Speculative stem cell futures: some prospective commercial models for induced pluripotent stem (iPS) cell based therapies. Journal of Futures Studies, 14(4), 85-96.

Heinonen, T. (2015). Management of innovation in academia: a case study in Tampere. Journal of Technology Management and Innovation, 10(2), 198-210.

Hekkert, M. P., Suurs, R. A. A., Negro, S. O., Kuhlmann, S. \& Smits, R. (2007). Functions of innovation systems: a new approach for analysing technological change. Technological Forecasting and Social Change, 74(4), 413-432. 
Hellman, K. B., Johnson, P. C., Bertram, T. A., \& Tawil, B. (2011). Challenges in tissue engineering and regenerative medicine product commercialization: building an industry. Tissue Engineering Part A, 17(1-2), 1-3.

lanmarino, S. \& McCann, P. (2006). The structure and evolution of industrial clusters: Transaction, technology and knowledge spillovers. Research Policy, 35, 1018-1036.

Johnson, P., Bertram, T., Tawil, B. \& Hellman, K. (2011). Hurdles in tissue engineering/regenerative medicine product commercialization: a survey of North American academia and industry. Tissue Engineering: Part A, 17(1-2), 5-15.

Kotiranta, A., Nikulainen, T., Tahvanainen, A., Deschryvere, M. \& Pajarinen, M. (2009). Evaluation of national innovation systems - key insights from the Finnish innoeval survey (Discussion papers No. 1196). Retrieved from https://www.etla.fi/wp-content/uploads/2012/09/dp1196.pdf

Kuhlmann, S. \& Arnold, E. (2001). RNC in the Norwegian research and innovation system (Background report No 12 in the evaluation of the Research Council of Norway). Retrieved from https://www.regjeringen. no/globalassets/upload/kd/vedlegg/forskning/rapporter/2001-rcneval/2001-rcn-evaluation-background-report-no-12.pdf

Lindvall, O. \& Hyun, I. (2009). Medical innovation versus stem cell tourism. Science, 324, 1664-1665.

Marshall, C., \& Rossman, G.B. (1999). Designing qualitative research. London: Sage.

Martin, P. A., Coveney, C., Kraft, A., Brown, N., \& Bath, P. (2006). Commercial development of stem cell technology: lessons from the past, strategies for the future. Regenerative Medicine, 1(6), 801-807.

Mason, C. (2007). Regenerative medicine 2.0. Regenerative Medicine, 2(1), 11-18.

Mason, C., Brindley, D., Culme-Seymour, E. \& Davie, N. (2011). Cell therapy industry: Billion dollar global business with unlimited potential. Regenerative Medicine, 6(3), 265-272.

Mason, C. \& Dunnil, P. (2008a). A brief definition of regenerative medicine. Regenerative Medicine, 3(1), 1-5.

Mason, C. \& Dunnil, P. (2008b). The need for a regen industry voice. Regenerative Medicine, 3(5), 621-631.

Mason, C. \& Manzotti, E. (2009). Regen: the industry responsible for cellbased therapies. Regenerative Medicine 4(6), 783-785.

McMahon, D. \& Thorsteinsdottir, H. (2013). Pursuing endogenous high-tech innovation in developing countries: A look at regenerative medicine innovation in Brazil, China and India. Research Policy, 42, 965-974.

Mesimäki, K., Lindroos, B., Törnvall, J., Mauno, J., Lindqvist, C., Kontio, R., Miettinen, S. \& Suuronen, R. (2009). Novel maxillary reconstruction with ectopic bone formation by GMP adipose stem cells. International Journal of Oral and Maxillofacial surgery, 38, 201-209. 
Messenger, M. \& Tomlins, P. (2011). Regenerative medicine: A snapshot of the current regulatory environment and standards. Advanced Materials, 23(12), H10-H17.

Metcalfe, J.S., James, A. \& Mina, A. (2005). Emergent innovation systems and the delivery of clinical services: the case of intra-ocular lenses. Research Policy 34, 1283-1304.

Murray, F. (2002). Innovation as co-evolution of scientific and technological networks: exploring tissue engineering. Research Policy, 31, 1389-1403.

Murray, F. (2004). The role of academic inventors in entrepreneurial firms: sharing the laboratory life. Research Policy, 33, 643-659.

Parson, A. (2008). Stem cell biotech: seeking a piece of the action. Cell, 132(4), 511-513.

Pavitt, K. (1984). Sectoral patterns of technical change: towards a taxonomy and a theory. Research Policy, 13, 343-373.

Polak, J., Bravery, C. \& Prescott, C. (2010). Translation and commercialization of regenerative medicine. Journal of the Royal Society Interface, 7(53), S675-S676.

Porter, M. E. (1990). The competitive advantage of nations. With a new introduction by the author. New York: Palgrave.

Prescott, C. (2011). The business of exploiting induced pluripotent stem cells. Philosophical Transactions of the Royal Society B, 366(1575), 2323-2328.

Salter, B., Zhou, Y. \& Datta, S. (2014). Health consumers and stem cell therapy innovation: markets, models and regulation. Regenerative Medicine, 9(3), 353-366.

Saxenian, A. (1994). Regional Advantage: culture and competition in Silicon Valley and Route 128. Cambridge. Massachusetts: Harvard University Press.

Sotarauta, M., \& Mustikkamäki, N. (2015). Institutional entrepreneurship, power, and knowledge in innovation systems: institutionalization of regenerative medicine in Tampere, Finland. Environment and Planning C: Government and Policy, 33(2), 342-357.

Stoerring, D. (2007). Emergence and growth in high technology clusters (Ph.D. dissertation), Dept. Of Business Studies, Åalborg University.

Stoerring, D. \& Dalum, B. (2007). Cluster emergence: a comparative study of two cases in North Jutland, Denmark. In P. Cooke \& D. Schwartz (Eds.), Creative regions: technology, culture and knowledge entrepreneurship (pp. 127-147). London: Routledge.

Yin, R. K. (1989). Case study research: design and methods. Applied Social Research Series, Vol. 5. London: Sage. 


\begin{abstract}
Abstrakt (in Polish)
Klastry sq istotnym elementem regionalnych gospodarek, a rozwijajqce się klastry majq szczególne znaczenie dla dywersyfikacji działalności gospodarczej poprzez nowe technologie i branże. Branże oparte na nauce sq $w$ tej dziedzinie szczególnie obiecujqce dla tworzenia i wsparcia wizji rozwoju określonych terytoriów, dzięki innowacjom przełomowym lub wzbogaceniu obecnych modeli gospodarczych, działających w tradycyjnych sektorach. Branża medycyny regeneracyjnej (MR) stanowi przykład takich wyłaniajacych się klastrów. Branża ta jest silnie zależna od badań naukowych, co oznacza, że region musi inwestować w badania naukowe w tej dziedzinie, by spodziewać się określonego zwrotu z inwestycji. Regiony zazwyczaj nie posiadajq rozwiniętych klastrów w dziedzinie $M R$, stąd branże te powinny wyłonić się $z$ istniejacych dziedzin działalności lub poszerzyć obecne sektory. Medycyna regeneracyjna angażuje szeroki zestaw technologii i sektorów, które mogq tworzyć klaster i korzystać z jego efektów, jeśli projekt odniesie sukces. W artykule zrealizowano dwa cele. Po pierwsze, przedstawiono bariery, które ograniczaja rozwój młodych klastrów. Po drugie, określono w jaki sposób w klastrach tego rodzaju powstajq innowacje $i$ jakie jest ich znaczenie dla danego terytorium. Na podstawie przeglqdu literatury przedstawiono rynek technologii i komercjalizacji w sektorze MR. Badanie empiryczne oparto na rozwijajqcym się klastrze MR w regionie Tampere, w Finlandii. Na podstawie 24 wywiadów przedstawiono kontekst tworzenia klastra w Tampere, gdzie sfera nauki inspiruje i stymuluje rozwój tej branży. Jednym z celów uniwersytetu jest komercjalizacja badań $w$ dziedzinie $M R$, jakkolwiek na razie brak komercyjnych rezultatów. Badanie ma znaczenie dla zrozumienia rozwoju młodego klastra w branży opartej na nauce, w fazie zalqżkowej i na wczesnych etapach rozwoju. Wskazano główne wyzwania dla powstającego klastra, które to wyzwania wymagaja dostosowania polityki wsparcia na poziomie mezo-ekonomicznym. Dla klastrów opartych na wiedzy niezbędna jest ukierunkowana polityka, a określone sektory, na danym etapie rozwoju potrzebujq specyficznych narzędzi polityki, aby osiqgną́ fazę dojrzałości.
\end{abstract}

Słowa kluczowe: medycyna regeneracyjna, wyłaniajacy się klaster, komercjalizacja, innowacja, blok kompetencji, rynek technologii.

\title{
Biographical notes
}

Tuomo Heinonen is a Ph.D. student in the School of Management, University of Tampere. He holds a M.Sc. in Technology from Tampere University of Technology. His research interests include management of innovation, commercialization and technology transfer, and regenerative medicine sector emergence.

Francisco Javier Ortega-Colomer holds a Ph.D. from Universitat Politècnica de València. His research interests focus on the analysis of the role of institutions and their innovative behavior, mainly in low-tech industries, from a qualitative perspective. He has (co)published several reports, research 
articles and papers at (inter)national conferences on these issues. He has been visiting researcher at several European and Latin American universities and has participated in research projects at European level related to the analysis of the contribution of PhD holders in Social Sciences and Humanities (eg. POCARIM). 